DOI: $10.20472 /$ IAC.2017.031.038

\title{
CHULEEWAN PRANEETHAM
}

Suratthani Rajabhat University, Thailand

JITTREE SAITHONG

Suratthani Rajabhat University, Thailand

BENYA JARIYAWIJIT

Suratthani Rajabhat University, Thailand

\section{SASITHON UCHUPONGSATHON}

Suratthani Rajabhat University , Thailand

WARUNSIRI PRANEETHAM

Suan Sunandha Rajabhat University, Thailand, Thailand

\section{CROSS-CULTURAL COMPETENCE OF STUDENTS : A CASE STUDY OF INTERNATIONAL SCHOOL OF TOURISM}

\begin{abstract}
:
Cultural Competence is a concept about learning proper principles of another culture to be applied to the daily life of people in the era of globalization with cultural and racial diversities, advances in science and technology, which people can quickly and easily communicate with others. These issues may affect human's way of life, beliefs, attitudes and behaviors towards cultural diversity. The integration of the ASEAN Economic Community is one of the factors contributing to the increasing of cultural exchanges, as well as rapidly changes in demographic, economic, and political and social environment may be the cause of cultural adaptation that people are facing and these could lead to a conflict of cultures. Nowadays, focusing the study on cultural competence is very important for education. The purpose of the study can lead promote cultural and cross-cultural competence of students, and raise their cultural awareness, cultural knowledge, and cultural skill on other cultures.
\end{abstract}

\section{Keywords:}

competence, cross-cultural, students

JEL Classification: 129 


\section{Introduction}

In the era of borderless world of information, the information and knowledge are possibly exchanged through the advancement of information technology worldwide (Ruengwanich, 2012). Currently, the world situation has changed rapidly and affected to human's way of living. The development has an impact on quality of human life and human well-being. Humans from different ethnic groups, culture or language have the opportunity to communicate without borders. Communication is not connected via cable, satellite or telecommunications systems only, but there is also cross-cultural communication in the form of interpersonal communication as well. With the opening of the ASEAN Economic Community (AEC), the ten countries of the ASEAN community members, namely: Brunei, Cambodia, Indonesia, Laos, Malaysia, Myanmar, the Philippines, Singapore, Thailand, and Vietnam focus on enhancing and increasing the capacity and competitiveness in bargaining power between countries. Therefore, people must adapt themselves to compete and be ready for the changes (Prompanyo, et al., 2013; Kosol and Suttawet, 2014). The enormous growth of economic, tourism and travel industry will cause changes in the economic, social, and cultural structures and people's way of living. The readiness preparation in every aspect is necessary to support the free movement of labor and mobilization to develop a network of cooperation with other countries to create intellectual capital and innovation.

Towards the AEC, it is likely that the number of visitors, tourists, and migrants to Thailand will increase. The entry of different culture could result in changes of culture and cause a clash of cultures which lead to conflict, problem and changing of culture (Haicharoen, 2003). Cultural diffusion, rapid change in technology, technology production and many other reasons could affect cultural changes and make the cultural rift (Yod Santisombat, 1997). In Thailand found that the issue of cultural competence is not yet widespread studied. While research abroad found that cultural competence was applied in evaluation and assessment of the social sciences and education. Recently, the education focuses more on cultural competence and finds that the cultural competence is necessary.

The International School of Tourism (IST) of Suratthani Rajabhat University provides 3 essential curriculums, namely: 1) Bachelor of Arts Program (Tourism: Thai Programme), 2) Bachelor of Arts Program (Airline Business: Thai Programme), and 3) Bachelor of Business Administration Program (Global Management of the Tourism and Hospitality Industry: English Program). According to the Thai Qualifications Framework for Higher Education (TQF: HEd), the graduates should have the ability and commitment to engage in lifelong learning, capacity for effective communication including communication through use of information technology and the ability to take the initiative in individual and group activities. The framework groups the kinds of learning expected of students into five domains and describes learning outcomes at each level in each of these groupings. The five domains are: ethical and moral development, knowledge, cognitive skills, interpersonal skills and responsibility, and 
analytical and communication skills (Office of the Higher Education Commission, 2009; Satjachaleaw and Sritawee, 2016). All Thai higher education institutions have to follow the Thai qualifications framework for higher education policies in order to meet the same education standards (Pornphol and Saejueng, 2013). Hence, the students who study at the IST are expected to have abilities, ethics, morals, and professional skills in tourism industry. They should promote and support the local environment preservation for sustainable tourism (Satjachaleaw and Sritawee, 2016).

The International School of Tourism provides teaching and learning to students, both Thai and international students. Foreign students comprise of Chinese, Vietnamese, Indonesian, and Burmese students. Encounter things unfamiliar such as people, values, language, food, customs and traditions that differ from their original culture may cause students' anxiety about safety, fear of touch with the people in a new culture, loneliness, isolation, and despair. The students are facing cultural adaptation. Therefore, the researchers are interested in studying cross-cultural competence of students in order to prepare them to support the AEC. Data from the study can be used as a guideline in planning, designing teaching and learning, or organizing projects for students in order to achieve educational results as targeted. Moreover, it could promote cultural and cross-cultural competence of students; provide students with the knowledge, understanding social, religious and cultural differences, have more awareness, attitudes, values, knowledge and skills on another cultural. However, the cultural adjustment of the individual is depending on the duration of his residence, the difference between the old culture to a new culture, attitude, and individual behavior.

\section{The Purposes of the Research}

The objectives of this research were:

1) To study the level of cross-cultural competence of students from the International School of Tourism.

2) To investigate factors influencing students' cross-cultural competence.

\section{Methodology}

The population and samples in this study were 40 foreign students, who did not have Thai nationality, studied at the International School of Tourism of Suratthani Rajabhat University, Surat Thani province, Thailand, surveyed by purposive sampling target group in Semester II, Academic Year 2016. The research instrument was the closeended questionnaire. The mean, frequency, percentage, standard deviation, t-test, One-Way-ANOVA were used to analyze the data. 


\section{Results}

The research findings from the study of students' cross-cultural competence are shown in Tables $1-5$ below.

Table 1: Demographic Characteristics of Respondents

\begin{tabular}{|c|c|c|}
\hline \multicolumn{3}{|l|}{ Characteristics } \\
\hline Sex & Frequency & Percent \\
\hline Male & 13 & 32.5 \\
\hline Female & 27 & 67.5 \\
\hline Total & 40 & 100.0 \\
\hline Age & Year & Percent \\
\hline Less than 19 Years old & 0 & 0 \\
\hline $19-20$ Years old & 13 & 32.5 \\
\hline 21 - 22 Years old & 24 & 60 \\
\hline More than 22 Years old & 3 & 7.5 \\
\hline Total & 40 & 100.0 \\
\hline Education Level & Frequency & Percent \\
\hline Freshman & 4 & 10.0 \\
\hline Sophomores & 10 & 25.0 \\
\hline Juniors & 26 & 65.0 \\
\hline Seniors or above & 0 & 0 \\
\hline Total & 40 & 100.0 \\
\hline Nationality & Frequency & Percent \\
\hline Chinese & 31 & 77.5 \\
\hline Vietnamese & 6 & 15.0 \\
\hline Indonesian & 1 & 2.5 \\
\hline Burmese & 2 & 5.0 \\
\hline Total & 40 & 100.0 \\
\hline
\end{tabular}


From Table 1, the result showed that the respondents of this study were 40 foreign students. Most of them were female with $67.5 \%$. The ages were between $21-22$ years old with $60 \%$. Most of the respondents were third year students with $54.6 \%$, and most had Chinese nationality with $77.5 \%$.

Table 2: Results of the Cross-Cultural Competence of Students.

\begin{tabular}{c|c|c|c}
\hline \hline Variable & $(\bar{x})$ & SD & Meaning \\
\hline Cultural Knowledge & 3.65 & 0.76 & good \\
Cultural Awareness & 3.85 & 0.63 & good \\
Cultural Skill & 4.04 & 0.49 & good \\
Cross-cultural Communication & 3.81 & 0.63 & good \\
Working as a Team Across the & 3.82 & 0.50 & good \\
Various Cultures & & & \\
\hline Total & 3.83 & 0.50 & good \\
\hline
\end{tabular}

From Table 2, the result showed that the overall cross-cultural competence of the foreign students was at good level (Mean $=3.83, S D=0.50$ ). The students' cultural knowledge, cultural awareness, cultural skill, cross-cultural communication, and working as a team across the various cultures were all at "good" level; which were $3.65,3.85,4.04,3.81$ and 3.82 respectively.

Table 3: Comparison of the Students' Cultural Knowledge, Cultural Awareness, Cultural Skill, Cross-Cultural Communication, Working as a Team across the Various Cultures, and Overall Cross-Cultural Competence by Gender.

\begin{tabular}{c|c|c|c|c|c|c}
\hline \hline \multirow{2}{*}{ Variable } & \multicolumn{2}{|c|}{ Male } & \multicolumn{2}{c|}{ Female } & \multirow{2}{*}{ t-value } & p-value \\
\cline { 2 - 5 } & $(\bar{x})$ & SD & $(\bar{x})$ & SD & .685 & .497 \\
\hline $\begin{array}{c}\text { Cultural } \\
\text { Knowledge }\end{array}$ & 3.77 & 0.73 & 3.59 & 0.78 & .685 \\
\hline $\begin{array}{c}\text { Cultural } \\
\text { Awareness }\end{array}$ & 3.88 & 0.72 & 3.83 & 0.59 & .240 & .812 \\
\hline $\begin{array}{c}\text { Cultural Skill } \\
\text { Cross-Cultural } \\
\text { Communication }\end{array}$ & 3.99 & 0.61 & 4.06 & 0.44 & -.424 & .674 \\
\hline $\begin{array}{c}\text { Working as a } \\
\text { Team across the } \\
\text { Various Cultures }\end{array}$ & 3.84 & 0.45 & 3.81 & 0.53 & .119 & .906 \\
\hline $\begin{array}{c}\text { Cross-Cultural } \\
\text { Competence }\end{array}$ & 3.86 & 0.60 & 3.82 & 0.46 & .223 & .824 \\
\hline \hline
\end{tabular}

${ }^{*} \mathrm{P}<0.05$

From Table 3, it can be derived that male and female had no difference in all crosscultural competence level $(p>0.05)$. 
Table 4: Comparison of the Students' Cross-Cultural Competence by Age.

\begin{tabular}{|l|c|c|c|c|c|}
\hline \multicolumn{1}{|c|}{$\begin{array}{c}\text { Source of } \\
\text { Variation }\end{array}$} & $\begin{array}{c}\text { Sum of } \\
\text { squares }\end{array}$ & Df & $\begin{array}{c}\text { Mean } \\
\text { Square }\end{array}$ & F & p-value \\
\hline Between Group & .496 & 2 & .248 & .985 & .383 \\
Within Group & 9.318 & 37 & .252 & & \\
Total & 9.814 & 39 & & & \\
\hline
\end{tabular}

${ }^{*} \mathrm{P}<0.05$

From Table 4, the results of One-way ANOVA showed that the students who had different age had no difference in cross-cultural competence level $(p>0.05)$.

Table 5: Comparison of the Students' Cross-Cultural Competence by Education.

\begin{tabular}{|l|c|c|c|c|c|}
\hline \multicolumn{1}{|c|}{$\begin{array}{c}\text { Source of } \\
\text { Variation }\end{array}$} & $\begin{array}{c}\text { Sum of } \\
\text { squares }\end{array}$ & Df & $\begin{array}{c}\text { Mean } \\
\text { Square }\end{array}$ & $\mathrm{F}$ & $\mathrm{p}$-value \\
\hline Between Group & .005 & 2 & .002 & .009 & .991 \\
Within Group & 9.809 & 37 & .265 & & \\
Total & 9.814 & 39 & & & \\
\hline
\end{tabular}

${ }^{*} \mathrm{P}<0.05$

From Table 5, the result showed that the students who had different education level had no difference in cross-cultural competence level $(p>0.05)$.

\section{Discussion}

The result indicated that the students' cross-cultural competence in the dimensions of cultural knowledge, cultural awareness, cultural skill, cross-cultural communication, and working as a team across were at "good" level.

The result revealed that the variables sex, age and education did not affect the students' cross-cultural competence. However, the ASEAN Economic Community, perception of modern culture and social change may affect people's way of living and has impact on the culture, society, and economy. The imitative behavior, both in dress and lifestyle may cause conflict between the people and it may result in loss of cultural identity to the original. Therefore, everybody has to prepare in all aspects to be able to respond and prepare for the changes that are caused by the ASEAN Economic Community (Ayuwat and Chamaratana, 2013).

Sangwipak (2014) pointed out that the AEC brings people into increasing of new cultural differences and cultural exchange among the member countries. This may 
lead to cultural conflict (Culture Clash) or may cause a sense of their culture to be better than another culture (Culture Chauvinism). A group of people who will be suffered from encounter different cultures and it is necessary to prepare for the crosscultural adaptation comprised of eight groups, namely; 1) tourists 2) international students 3) business sojourners 4) spouses and children 5) immigrants 6) refugees 7) business expatriate and 8) International Business Man. Thus, these eight groups of people should prepare themselves for cultural encounter with a different culture. It can reduce the probability of occurrence of cultural depression (Culture Shock) at a certain level. Therefore, it should have extended the concept of the culture immensely to the population of the ASEAN member countries. The citizens of the Member States should have a deep understanding of the cross-culture correctly. This could be one way to reduce cultural conflicts.

\section{Acknowledgement}

The authors would like to acknowledge financial support from Suratthani Rajabhat University. Any errors are the responsibility of the authors.

\section{References}

Ayuwat, D. and Chamaratana, T. (2013). Perception of ASEAN Economic Community of Yasothon Tourism Laborers. In Proceedings of the 3th Annual Sustainable Rural Development.

Haicharoen, W. (2003). Homestay Tourism Management for the Conservation of the Environment : A Case Study of Koh Yao Noi Community, Phang-Nga province. Master of Arts (Environment) Graduate School, Mahidol University.

Kosol, O. and Suttawet, C. (2014). Sustainable Tourism Management for Supporting ASEAN Economics Community. Journal of Politics and Governance, 4, pp. $200-232$.

Office of the Higher Education Commission. (2009). Thai Qualifications Framework for Higher Education 2009. Bangkok : Office of the Higher Education Commission.

Pornphol, P. and Saejueng, C. (2013). The Information Technology for Thai Qualifications Framework for Higher Education. Official Conference Proceedings of the Asian Conference on Society, Education and Technology 2013.

Ruengwanich, P. (2012). Using of Technology for Knowledge Management of Bachelor of Arts Program: Human Resource Development, Ramkhamhaeng University. Classroom Research Report. Faculty of Human Resource Development, Ramkhamhaeng University.

Prompanyo, M., et al. (2013). Management Guideline for Religious Tourism toward the ASEAN Community: Ubonratchathani Province. Journal of Thai Hospitality, 8, pp. 36-47.

Sangwipak, A. (2014). Cultural Learning Processes that Essential toward and ASEAN Economic Community (AEC). Sripatum Journal, 11(1), pp.19-26. 
Satjachaleaw, N. and Sritawee, S. (2016). Students' Motivations for Choosing Foreign Language: International School of Tourism, Suratthani Rajabhat Univeristy. In Proceedings of Arts \& Humanities Conference, Venice, pp. 164-169.

Yod Santisombat. (1997). Man and Culture. Bangkok: Thammasat University. 